\title{
THE GENETICAL SOCIETY OF GREAT BRITAIN
}

\author{
ABSTRACTS of papers presented at the HUNDRED AND EIGHTY SECOND \\ MEETING of the Society held on 12th and 13th November, 1976 at \\ UNIVERSITY COLLEGE, LONDON.
}

\author{
A GENETIC STUDY OF WELSH GYPSIES \\ E. MAIR WILLIAMS and P. S. HARPER \\ Section of Medical Genetics, Welsh National School of Medicine, Cardiff
}

A study of an isolated and inbred group of Welsh Gypsies of Romany origin has shown a high incidence of phenylketonuria and other recessively inherited disorders. A high coefficient of consanguinity $(F=0.017)$ was found, and known consanguineous marriages showed an increased incidence of non-specific mental subnormality and of spontaneous abortions. Data on genetic disorders in other gypsy populations have been collected, and studies on genetic markers in the Welsh Gypsies will be discussed in relation to the possible origins of the Gypsies.

\section{CYTOGENETICS OF THE GREAT APES (PAN TROGLODYTES, GORILLA GORILLA, PONGO PYGMAEUS) AND THEIR RELATIONSHIP TO MAN}

\author{
HECTOR SEUANEZ and JUDY FLETCHER \\ Medical Research Council, Clinical and Population Cytogenetics Unit, \\ Western General Hospital, Edinburgh
}

Chromosome banding techniques have permitted a more detailed comparison of the chromosomes of the hominidea, and has revealed homologies between the chromosomes of man and the great apes (Dutrillaux, in; Sur la Nature el l'origine des chromosomes humains, 1975).

Chromosome polymorphisms have been found by us in the three species studied, using G- Q- and C-banding techniques. A complex chromosome rearrangement Inv(9) (p 13 $\mathrm{q} 13)$; ins (p13 q21 q21 p13) has been found in chromosome No. 9 in the orang-utan (Pongo pygmaeus) and was present in 10 of 20 animals studied. Two of the ten carriers were homozygous, and there is evidence that both homozygous and heterozygous have a normal fertility. Carriers of this variant chromosome type belonged to both populations of $P_{\text {ongo }}$ (Sumatran and Bornean) which are naturally isolated from each other.

It is therefore concluded that this complex rearrangement in Pongo has an ancient origin and has been maintained as a balanced type of polymorphism. This type of chromosome polymorphism in Pongo is compared to chromosome polymorphisms in man, the Pongidae and mammalian populations in general. The role of pericentric inversions in chromosome evolution of the hominidea is discussed.

\section{SATELLITE DNAS IN MAN AND THE HOMINOID APES}

\section{J. R. GOSDEN, H. SEUANEZ, A. R. MITCHELL, S. LAWRIE, D. MARTIN, J. FLETCHER and C. M. GOSDEN}

\section{M.R.C. Clinical and Population Cytogenetics Unit, Western General Hospital, Edinburgh}

The location of four human satellite DNA's in human chromosomes has been determined by in situ hybridisation (Gosden et al., Exp. Cell Res., 92, 148, 1975). The method used for analysing the results has permitted a quantitative distribution of these DNA sequences to be calculated.

DNA sequences which hybridise with human satellite cRNAs are present in the hominoid apes, and the location of these sequences in the chimpanzee (Pan troglodytes), gorilla (Gorilla gorilla) and orang-utan (Pongo pygmaeus) has been investigated by the same method. 
The distribution of these human DNA sequences in the hominoid apes confirms that their sequences are quite distinct, and that their common hybridisation at many sites in man does not arise from their cross reaction. The relationship between the distribution of thcse scqucnces and chromosome homologics determined by banding patterns suggests that such homology does not necessarily include repeated DNA sequences. Possible modes of evolution of the human satellite DNAs and their relation to the phylogeny of the Hominoidea will be discussed.

\title{
RESTRICTION ENZYME STUDIES ON HUMAN SATELLITE 3 DNA
}

\author{
A. R. MITCHELL and C. J. BOSTOCK \\ Medical Research Council, Clinical and Population Cytogenetics Unit, \\ Western General Hospital, Edinburgh
}

Human satellite 3 DNA (Corneo, Ginelli and Polli, BBA 247, 528, 1971) has been isolated from total human DNA and its sequence complexity has been examined using the restriction enzyme HaeIII from Haemophyllis aegyptius. The digested DNA gives characteristic size products when separated on 1.5 pcr cent agarose gels with a monomer size of around 200 nucleotide pairs. The restriction profile has been used to examine DNA satellite III sequences from a variety of cell types and differences in the profiles have been correlated with differences in chromosome karyology. In particular satellite III from normal male cells contains two major bands which are absent from satellite III sequences isolated from female cells. $46, \mathrm{XX}$ cells containing a translocation of the distal quinacrinebright part of the $Y$ onto chromosome 22 and cells obtained from individuals with particular variants of the fluorescent region (Q-band) of the Y chromosome have becn used in an attempt to precisely locate these "male" satellite III sequences. These results will be discussed together with other data suggesting that satellite III sequences which are located in different chromosomes have different HaeIII digestion profiles.

\section{CHROMOSOMAL ABNORMALITIES INDUCED IN VICIA FABA BY INHALATIONAL ANAESTHETICS}

\author{
C. J. GRANT and J. N. POWELL \\ Departments of Botany and Anoesthetics, University of Bristol
}

\begin{abstract}
Although chromosomes exposed to inhalational anaesthetics during mitosis and examined at once show no apparent damage, the chromatin bridges and micro-nuclei found in subsequent interphase cells in animal and plant systems indicate that such abnormal cells might show chromosome damage if they can replicate and proceed to a further mitosis.

When bean root tips in water culture are exposed for 2 hours to clinical concentrations of halothane or methoxyfluorane in air or to halothane in 80 per cent nitrous oxide in oxygen, there is a transient increase in Mitotic Index and then abnormal interphase cells are produced in proportion to the anaesthetic concentration used. The frequencies of these abnormalities can be correlated with the accumulation of metaphase ceils during exposure. After exposure there is a period of mitotic inhibition during which the cells become partially synchronised.

Colchicine metaphases examined 28 hours after exposure and compared with controls and with metaphases collected 4 hours after exposure, show a significant increase in the number of cells showing aneuploidy, tetraploidy, and the results of chromosome breakage.
\end{abstract}

\section{HYBRIDISATION OF CULTURED CHINESE HAMSTER KUPFFER CELLS POSSESSING QUANTITATIVE DIFFERENCES IN SEVERAL ENZYME ACTIVITIES}

\author{
J. M. CLARK and J. A. PATEMAN \\ Institute of Genetics, University of Glosgow
}

The technique of somatic cell hybridisation has been used to examinc the phenotype of hybrid cells dcrived from parental cell lincs with presumed identical genetic and developmental background but differing with respect to the activities of several enzymes. 
Kupffer cell lines were initiated from a Chinese hamster and the actitities of $\beta$-glucuronidase, arginase, lactate dehydrogenase (LDH), alcohol dehydrogenase (ADH), isocitrate dehydrogenase (IDH) and glucose-6-phosphate dehydrogenase (G6PDH) determined. The enzymes demonstrated up to a ten-fold range in activity between the cell lines. Cell lines with the most extreme activities of each enzyme provided parental cells for hybridisation studies. Clones resistant to either ouabain or vinblastine were obtained from the parental cell lines and hybrids selected in medium containing ouabain and vinblastine.

Enzyme activities in the hybrid clones derived from parental cells with " high" and " low" enzyme activity demonstrated two different patterns. Arginase and $\beta$-glucuronidase activities were intermediate between those in the parental cells and provided no indication of interaction between the parental genomes.

Catalase, LDH, ADH, IDH and G6PDH possessed activities characteristic of the " high" activity parental cells and it is suggested that for these five enzymes one parental genome is exerting an influence on the other parental genome. Previous studies with the Kupffer cell lines have indicated that there may be co-ordinate regulation of these five enzyme activities.

The results indicate that hybridisation of cell lines derived from an identical source but possessing quantitative differences in enzyme activities may be of value in the study of genetic regulation in mammalian cells.

\title{
HERITABLE FRAGILE SITES ON HUMAN CHROMOSOMES
}

\section{G. R. SUTHERLAND}

Cytogenetics Unit, Deportment of Histopathology, Adelaide Children's Hospital, South Australia

Heritable fragile sites have been described on the long arms of chromosomes 2, 16 and several $\mathrm{C}$ group chromosomes which were not positively identified. A similar site on the $\mathrm{X}$ at band $\mathrm{q} 27$ or 28 is associated with some forms of mental retardation. The frequency of observation of these sites has been found to vary according to the type of culture medium in which the lymphocytes used for chromosome study are grown. The sites are seen most frequently when the lymphocytes are cultured in medium 199 but are only rarely seen when the following media are used: RPMI 1640, Ham's F10, Eagles basal, CMRL 1969. The results of these findings will be presented and their implications discussed.

\section{SYNERGISM BETWEEN THE TIF-1 AND PLASMID-ENHANCED MUTATOR EFFECTS IN ESCHERICHIA COLI}

\author{
O. P. DOUBLEDAY and B. A. BRIDGES
}

MRC Cell Mutation Unit, University of Sussex

The mutator effects in Escherichia coli of temperature-sensitive if -1 expression and of the pKM 101 plasmid show positive synergism with each other and with the effect of ultraviolet light. The mutator effect of the plasmid is thus not equivalent to a constitutive expression of tif-1. The results will be discussed in the light of current models of mutagenesis.

\section{GAMMA RADIATION AND ULTRAVIOLET LIGHT MUTAGENESIS IN A TIF-1 STRAIN OF ESCHERICHIA COLI}

\section{B. A. BRIDGES}

\section{MRC Cell Mutation Unit, University of Sussex}

In the non-filamenting tif- 1 strain WP44 $4_{s}$ NF trp a dramatic enhancement of both UV and gamma ray mutability to $\mathrm{Trp}^{+}$was observed when irradiated bacteria were incubated on plates at $43^{\circ}$. This enhanced mutability was progressively suppressed when the initial plating density exceeded $10^{8}$ bacteria per plate and was not demonstrable in liquid media. Under optimal conditions more mutants were induced by gamma radiation than could reasonably be accounted for by the initial number of radiation-induced lesions in the DNA implying the existence of some mechanism for amplifying the radiation effect. Moreover, the tif-enhanced mutation frequency could be obtained if incubation in nutrient broth at restrictive temperature was delayed for up to 60 minutes after irradiation, at a time when all known reparable DNA damage had been repaired and the number of viable bacteria 
had more than doubled. On plates the effect of high temperature was still fully demonstrable 120 minutcs after irradiation. The results are hard to reconcile with the hypothesis that incubation of tif- 1 bacteria at restrictive temperature causes the induction of a repair system acting on DNA damaged by gamma radiation. A more compatible interpretation would be that radiation causes a persisting physiological disturbance in the cell and that this enhances the spontaneous mutator effect occurring in tif- 1 bacteria subjected to subsequent thermal shock.

\title{
HETEROCHROMATISATION AND THE POSSIBILITY OF GENE INACTIVATION IN B CHROMOSOMES OF PICEA GLAUCA
}

\author{
H. REES, S. B. TEOH and L. M. JONES \\ Department of Agricultural Botany, University College of Wales, Aberystwyth
}

It is generally agreed that supernumerary, B chromosomes are derived initially from members of the normal (A) chromosome complement. Individuals carrying a new B chromosome would therefore be trisomic for genes carried on the B. We would expect, as a characteristic consequence of the trisomy, a gross genetic imbalance, a drastic loss of fitness. We would expect, as well, multivalents involving A and B cliromosomes at meiosis with the likclihood of reduced fertility. Yet B chromosomes are found in more than 700 species. Their widespread establishment argues against the display of gross imbalance and in none of the species do the B's pair with A's at meiosis and form multivalents. It has been suggested that pairing between $A$ and $B$ chromosomes and the formation of $A / B$ multivalents at meiosis may have been circumvented by heterochromatisation of the $B$ chromosomes. It has been suggested, also, that inactivation of the genes on the B chromosomes in conjunction with the heterochromatisation, as in the inactivated mammalian $\mathrm{X}$ chromosome, would resolve the problem of imbalance due to polysomy. Evidence is presented which indicates facultative heterochromatisation of $\mathrm{B}$ chromosomes in White Spruce and the possibility of gene inactivation comparable to that of a mammalian $\mathrm{X}$.

\section{IMMUNOCHEMICAL ANALYSIS OF THE HUMAN N-ACETYL HEXO- SAMINIDASES IN HUMAN/MOUSE SOMATIC CELL HYBRIDS}

\author{
E. SOLOMON, D. M. SWALLOW and L. PAJUNEN \\ Genetics Laboratory, Oxford and MRC Human Biochemical Genetics Unit, Galton Laboratory, \\ University College, London
}

Two genes, thought to be located on chromosomes 15 and 5 , have been implicated in the expression of the human $\mathrm{N}$-Acetyl hexosarninidases, $H E X_{\mathrm{A}}$ and $H E X_{\mathrm{B}}$, respectively, It has becn unclear, however, whether both of these chromosomes are needed for the expression of $H E X_{\mathrm{A}}$, or whether it can be expressed independently of chromosome 5 . We have approached this problem by a combination of immunochemical and chromosome selection techniques, in the following manner.

$A$ hybrid was made with a human fibroblast line containing an $\mathrm{X} / 15$ translocation chromosome. This was then uscd in a double selection system to obtain hybrids of four different types with respect to the $\mathrm{X} / 15$ and chromosome $5: \mathrm{X} / 15^{+} 5^{+} ; \mathrm{X} / 15^{-} 5^{+} ; \mathrm{X} / 15^{+} 5^{-}$; $\mathrm{X} / 15^{-} 5^{-}$. The systems used were the standard positive and negative selections for the $\mathrm{X}$ chromosome and a negative selection for chromosome 5 using diphtheria toxin. Using thcse hybrids the assignments to chromosome 5 of $H E X_{\mathrm{B}}$ and the gene for sensitivity to diphtheria toxin were confirmed. A $H E X_{\mathrm{A}}$ band segregated with the $\mathrm{X} / 15$ chromosome independently of chromosome 5 , but this band could be distinguished from true $H_{E X}$ immunologically. True $H E X_{A}$ was present when both the $\mathrm{X} / 15$ and chromosome 5 were present.

\section{SOMATIC CELL GENETICS AND THE LHA SYSTEM}

\section{W. F. BODMER \\ Department of Biochemistry, University of Oxford}

Somatic cell hybridisation has provided the basis for the systematic analysis of cclls in culture, mainly by exploiting the segregation of human chromosomes in human-mouse and other similar interspecific hybrids. Markers can be linked together or assigned to chromosomes by association with a selected marker, or by random association of unselected 
markers. Regional localisation on the chromosome can be achieved by using human parental cells containing known translocations or by inducing chromosome breaks in the human parent. Examples of all these approaches to mapping will be discussed.

The application of somatic cell genetics to the HLA system has shown that it is on chromosome 6 , while the associated $\beta_{2}$ microglobulin is controlled by a gene on chromosorne 15. Some recent results on the mapping of HLA linked Ia determinants and the study of the genetic control of HLA expression will be reviewed.

\title{
PEDIGREE STUDIES
}

\author{
E. B. ROBSON \\ MRC Human Biochemical Genetics Unit, The Galton Laboratory, University College, London
}

Conventional linkage analysis in man by means of family studies used to be a desperately unrewarding business because of the relatively large number of polymorphic loci, the smallness of human families and the tedium of the search for informative families. Some of these factors cannot be changed, but some have been. The study of enzymes by electrophoresis has greatly increased the number of polymorphic loci testable on the most readily obtainable samples, those of blood, and advances in immunology have revealed many others. The assignment of loci to particular chromosomes was made much easier by the development of somatic cell hybridisation techniques. This has meant that pedigree studies can now be directed to more specific problems, more informative matings selected for analysis and much needless computation avoided. As yet only the products of some loci can be detected on cultured cells, so work on the mapping of red cell antigens, other specific tissue products and many diseases still remains the province of classical family studies. Fine structure mapping, as in the case of the HLA region; regional mapping using familial translocations, as exemplified by the map of chromosome 1 and the general characteristics of the recombination process in man are some of the problems currently under investigation.

\section{DUPLICATION AND DELETION MAPPING USING GENE DOSAGE IN MAN}

\author{
D. A. AITKEN and M. A. FERGUSON-SMITH \\ Institute of Genetics, University of Glasgow
}

A gene dosage effect correlated with an identifiable loss or gain of chromosome material may provide evidence for gene localisation. This approach has been successfully exploited to map the chromosomes of many species, but initial attempts proved erroneous in man. Quantitation of various white blood cell enzymes in patients trisomic for chromosome 21 revealed increases in activity which were clearly non-specific as they could also be demonstrated in other autosomal trisomies and some even occurred in enzymes whose loci were X-linked.

More recent evidence indicates that gene dosage can be demonstrated in red cells and used for gene assignments in patients with small chromosomal deletions defined by banding (Ferguson-Smith, M. A., Newman, B. F., Ellis, P. M., Thomson, D. M. G., Riley, I. D., Nature New Biol., 243, 271-274, 1973). Using a similar approach a 43 per cent increase in red cell adenylate Kinase (AK-1) activity has been found to be associated with duplication of the terminal band of the long arm of chromosome 9 (Ferguson-Smith, M. A., Aitken, D. A., Turleau, C. and de Grouchy, T. J., Human Genetics, 34, 35-43, 1976). This confirms the assignment of the AK-1 structural gene locus to chromosome 9 made in somatic cell hybrids and suggests that the ABO: Np-1: Ak-1 linkage group is located at the distal end of the long arm of chromosome 9.

A review of experience in duplication/deletion mapping suggests that, providing certain criteria can be fulfilled, the method is valid and deserves further application.

\section{GENE MAPPING USING OVARIAN TERATOMAS}

\section{S. POVEY}

\section{MRC Human Biochemical Genetics Unit, The Galton Laboratory, University College, London}

Benign ovarian teratomas, which are known to have a diploid karyotype, sometimes appear to be homozygous at loci for which the patient is heterozygous. Chromosomal 
and biochemical evidence suggests that the most likely explanation of this is failure of Meiosis II. If this is correct one would predict that the frequency of homozygosity in such tumours would depend on the distance of each locus from the centromere, and would be greatest in those loci lying closest to it. It is possible to test tissue or cultured cells from these teratomas for many of the polymorphic biochemical markers usually tested in families, and also for additional enzymes not expressed in red cells and thus less accessible to pedigree analysis. Data are available on up to 10 loci from approximately 100 teratomas and will be considered in relation to the human linkage map.

\title{
THE USE OF IN SITU AND MOLECULAR NUCLEIC ACID HYBRIDISATION IN HUMAN GENE MAPPING
}

\author{
R. WILLIAMSON, M. A. FERGUSON-SMITH and S. MALCOLM \\ Institute of Genetics, University of Glasgow
}

It is now possible to prepare specific gene products, such as pure messenger RNA for a single protein, and to label it, or a complementary copy of it, to a very high specific activity. Such radioactive probes can be used to study gene number and gene expression, since they hybridise to structural genes and to nuclear and cytoplasmic messenger RNA sequences.

Since such nucleic acid probes are gene-specific, they can be used to identify the position of genes on chromosomes or in interphase nuclei by in situ hybridisation. With remarkably small modifications, standard solution techniques for nucleic acid hybridisation also work for fixed cells challenged with a solution containing labelled mRNA or cDNA. Using such procedures, ribosomal $28 \mathrm{~S}$ and $5 \mathrm{~S}$ loci have been determined by various groups, and attempts have been made to locate the position of the globin genes. These have given apparently unequivocal results, although these arc confusing because many more sequences appear to hybridise than expected from the very low gene number.

Using cDNAs purified for complementarity to $\gamma$-globin and $\beta$-globin gene sequences, it has been shown that the intergene distance between them is at lcast 5000 nucleotide pairs, and that they are not co-expressed in a single large nuclear RNA molecule.

It should be possible to use these various techniques for antenatal diagnosis; this already being achieved for $\alpha$-thalassaemia by one group using molecular hybridisation, and by using recombinant DNA technology it should bc possible to extend it to diagnosis using in situ hybridisation for several other conditions where a "defective gene-characteristic probe" can be prepared.

\section{THE DETECTION OF $6+: 2 \mathrm{~m}$ AND $2+: 6 \mathrm{~m}$ ASCI WITH POSTMEIOTIC SEGREGATION, AND OF ABERRANT 4:4s, IN UNORDERED OCTADS OF ASCOBOLUS}

\author{
A. GHIKAS and B. C. LAMB \\ Department of Botany, Imperial College, London
}

By using combinations of visual markers, it is possible to identify visually certain types of postmeiotic segregation which are usually undetectable in unordered asci. A white $(w)$ ascospore mutant and a granular $(g r)$ pigmentation marker in the Pasadena strains of Ascobolus immersus have been used here. Relevant segregations, identified visually from phenotype ratios in octads, were confirmed by germinating spores, backcrossing to check genotypes, and testing for other segregating loci (mating type and parafluorophenylalanine resistance). Wild-type spores are red and non-granular, and $w$ is epistatic to $g r$; there arc three spore phenotypes: red non-granular $(R N)$, red granular $(R G)$ and white $(W)$.

At the white locus (iw-78), aberrant $4: 4$ segregations usually gave octad phenotype ratios of $3 R N, 1 R G, 4 W$ or $1 R N, 3 R G, 4 W$. Of much more interest were the $3 R N, 3 R G$, $2 \mathrm{~W}$ and $1 \mathrm{RN}, 1 \mathrm{RG}, 6 \mathrm{~W}$ octads, coming respectively from $6+: 2 w$ and $2+: 6 w$ ratios with postunciotic segregation for $w$. Lamb and Wickramaratne (Genet. Res., 22, 113, 1973) predicted the occurrence of such 6:2 and 2:6 classes arising from hybrid DNA formation at corresponding sites in both pairs of non-sistcr chromatids of a bivalent. With just two visual markers in a cross, postmeiotic segregations of the three kinds described will sometimes go undetected but formulae were derived to allow for these undetected ones, so the present data can be used in corresponding-site interference studies. 


\title{
THE RELEVANCE OF GENE CONVERSION DATA TO MODELS OF SYNAPTINEMAL COMPLEX STRUCTURE AND CHROMATID PAIRING IN MEIOSIS
}

\author{
B. C. LAMB \\ Department of Botany, Imperial College, London
}

\begin{abstract}
Various models of DNA pairing between homologous non-sister chromatids within the synaptinemal complex (SC) have been proposed, largely on the basis of electron microscope studies. Gene conversion data have often been ignored in such models yet can provide precise information on many aspects of pairing. For example, on several models only two of the four chromatids of a bivalent can pair at any one point along the SC, whilst conversion data from Ascobolus immersus (e.g. Lamb and Wickramaratne, Genet. Res., 22, 113, 1973) show clearly that both pairs of non-sister chromatids can pair (largely independently) at a single point in a bivalent.

Gene conversion studies in various fungi give information on chromatid arrangements during pachytene pairing, on the lengths of segments continuously paired at the DNA level and on the frequency of intimate pairing at particular sites. Different types of conversion ratio, corresponding-site interference, co-conversion and the range and distribution of conversion frequencies are all relevant to meiotic chromatid pairing and DNA pairing and DNA pairing within the synaptinemal complex.
\end{abstract}

\section{GENETIC CONTROL OF THE IMMUNE RESPONSE TO SALMONELLA TYPHIMURIUM IN MICE}

\author{
A. EBRINGER, P. WOOLEY and C. R. YOUNG \\ Immunology Unit, Departments of Biochemistry and Microbiology, \\ Queen Elizabeth College, London
}

The ability to produce adequate antibodies may be relevant in studying susceptibility to infection and disease.

Some strains of mice such as BALB/C are susceptible, whilst other strains such as CBA are relatively resistant to infection by Salmonella typhimurium micro-organisms.

The capacity of $\mathrm{CBA}$ and $\mathrm{BALB} / \mathrm{C}$ mice to produce an antibody response, independent of infectivity, was tested by immunisation with $2 \times 10^{7}$ ultraviolet inactivated Salmonella typhimurium micro-organisms.

Using a linear dilution Widal Assay, it was found that CBA mice produced a mean agglutinating dilution titre of $520 \pm 15$ (mean \pm S.E.), whilst BALB/C mice produced an antibody titre of $290 \pm 17$, following secondary immunisation, and this difference is statistically significant $(t=10.49, \mathrm{P}<0 \cdot 001)$.

It is suggested that " high responder" CBA mice may be relatively resistant to Salmonella typhimurium infections, because of their capacity to produce higher antibody responses than the susceptible "low responder" $\mathrm{BALB} / \mathrm{C}$ mice, and similar mechanisms may operate in other infectious diseases.

\section{ENDOPEPTIDASE PROCESSING OF THE COMPLEX PYR-3 GENE PRODUCT IN NEUROSPORA CRASSA}

\section{A. J. MAKOFF and A. RADFORD \\ Department of Genetics, University of Leeds}

Purification of the pyr-3 gene product of Neurospora (pyrimidine-specific carbamoyl phosphate synthetase and aspartate carbamoyl transferase structural gene) has proved to be complicated by shifts in the molecular weight of the enzyme complex. The native enzyme, possessing both CPS and ACT activities, has a molecular weight of 650,000, confirming the findings of Williams et al. (Biochemistry, 9, 4329 (1970)). The CPS activity is highly labile, and may be lost without molecular weight change. Disregarding a tendency of this form to form aggregates larger than $2 \times 10^{6}$ daltons, it undergoes dissociation to a form with only ACT activity at $10^{5}$ daltons. This shift can be inhibited by PMSF, suggesting the presence in crude and partially purified extracts of at least one protease. There is good evidence that this is, in fact, an endopeptidase, as similar changes in molecular weight 
and catalytic properties are brought about by trypsin, chymotrypsin, thermolysin, and elastase, but not by exopeptidases. Evidence from gel filtration demonstratcs the existence, in cell extracts, of a 12,000 dalton inhibitor of the physiological endopeptidase.

\title{
A HUMAN GENE FOR ARGINOSUCCINATE SYNTHETASE ON CHROMOSOME 9
}

\author{
B. CARRITT, P. S. G. GOLDFARB, M. L. HOOPER and C. SLACK \\ Institutes of Genetics and Virology, Glasgow
}

The Chinese harnstcr cell line Don has a growth requirement for arginine which can be satisfied by argininosuccinate but not by citrulline. Extracts of Don have arginosuccinase, but not argininosuccinate synthetase (ASS) activity. Analysis of somatic cell hybrids formed between Don and a diploid human fibroblast suggest that ASS expression is a dominant trait which segregatcs out of those clones which have lost the relevant human gene(s). The gene(s) may either be a human structural gene for ASS, or a human positive control element capable of activating a structural gene in Don.

40 primary Don-human hybrid clones were analysed with respect to the correlation between ASS expression and human chromosomes and linkage markers. Correlations at the 5 per cent level of significance were found for ASS with chromosomes 7, 10 and 15, and at the 0.3 per cent level with the human marker AK-1 on chromosome 9. Analysis of 30 subclones of $4 \mathrm{ASS}^{+}$primary clones weakened the correlation with chromosomes 7 , 10 and 15, and confirmed the concordant segregation of ASS with chromosome 9. Thcse data favour an assignment of a human ASS gene to chromosome 9.

\section{GENETIC POLYMORPHISM AND INTER-ETHNIC VARIABILITY OF PLASMA PAROXONASE ACTIVITY}

\author{
J. R. PLAYFER and D. A. P. EVANS \\ Department of Medicine, Liverpool University
}

Paroxon is the main metabolite of the anti-cholinesterase insecticide parathion. The biological activity of parathion is principally due to the activity of paroxon. Paroxonase, a plasma enzyme present in man, hydrolyses paroxon to paranitrophenol. Paroxonase activity can be measured by an auto-analyser. Frequency distributions for British and Indian populations show bimodality. A study of 40 British families demonstrates the presence of a genetic polymorphism. Two phenotypes, "low activity" and " high activity" can be defined, and are controlled by two alleles at one autosomal locus. The frequency for the gene in the British population is $q=0.7034$. The frequency of the low activity is less for an Indian population. Other ethnic groups (Malay, Chinese and African) fail to show obvious bimodality.

\section{AN ANALYSIS OF PROTEIN SYNTHESIS IN THE NEWLY FERTILISED EGG OF DROSOPHILA MELANOGASTER}

\section{B. ROBERTS and G. GRAZIOSI}

\section{Genetics Laboratory, Oxford University and Zoology Department, Trieste University}

Gene activity in the newly fertilised egg may be followed by studying protein synthesis but it is necessary to distinguish between those proteins which are translated from maternal message and those translated from zygote message. We have adapted the technique of Zalokar (Dev. Biol., 1973, 35, 382) to permeabilise a large number of Drosophila eggs and using ${ }^{35} \mathrm{~S}$ methionine we can study protein synthesis in the egg. Total protein synthesis in the early period after fertilisation up to cellular blastoderm is sensitive to inhibitors of protein synthesis but not of RNA synthesis. In the cellular blastoderm protein synthesis is sensitive to inhibitors of RNA synthesis. This suggests that if any mRNA is transcribed before cellular blastoderm from the zygote genome it is not translated until later.

Using antibodies prepared against different Drosophila extracts we identify some 50 proteins in newly fertilised eggs. A comparison of the proteins found in oocytes and unfertilised eggs with the proteins found in fertilised eggs and an autoradiographic study of the 
proteins of newly fertilised eggs allow us to classify proteins as those synthesised during oogenesis, those synthesised both during oogenesis and in early development and those translated from masked maternal mRNA in early development.

We have analysed female sterile inutants for changes in these proteins.

\title{
LATE LARVAL SERUM PROTEINS IN DROSOPHILA MELANOGASTER
}

\author{
M. E. AKAM, D. B. ROBERTS and J. WOLFE \\ Genetics Laboratory, Oxford University
}

Two major protein species account for 50 per cent of the haemolymph protein, and 10 per cent of the total protein of late third instar larvae.

These proteins (Larval serum proteins (LSP) 1 and 2) have been purified and used to prepare specific antisera with which their developmental profile has been assayed by quantitative immunoelectrophoresis. The synthesis of both is initiated after the second larval moult with the specific activity rising to a maximum in late third instar larvae and falling rapidly during the late stages of metamorphosis and early adult life. In vitro synthesis can be demonstrated by ${ }^{85} \mathrm{~S}$ methionine labelling in excised fat body.

Both proteins are aggregates (M.W. about 450,000 daltons) and are probably hexamers with SDS separable subunits of 75,000-80,000 daltons. LSP-2 is a homopolymer, for which fast and slow electrophoretic variants have been found. Both of these variants map to 37 on the left arm of chromosome 3 between the markers vin and gespleten.

LSP-1 includes a class of partially cross reacting molecules containing three types of subunit of slightly differing SDS mobilities. These may be either modified products of a single gene, or transcripts from tandemly repeated genes which have diverged in evolution.

\section{EVIDENCE FOR NON-RANDOM MITOTIC SEGREGATION OF SISTER CHROMATIDS IN SACCHAROMYCES CEREVISIAE}

\author{
D. H. WILLIAMSON and D. J. FENNELL \\ National Institute for Medical Research, Mill Hill, London
}

It has been reported that in certain plant and animal cells, as well as in the filamentous fungus Aspergillus, chromatids containing DNA template strands of the same age segregate together at mitosis, i.e. non-randomly (Lark et al., Science, 154, 1202, 1966; Lark, Proc. Nat. Acad. Sci. U.S., 58, 352, 1967; Rosenberger and Kessel, F. Bacteriol., 96, 1208, 1968).

We have used a procedure based on DNA-specific cell autoradiography to detect the occurrence of this phenomenon in the yeast Saccharomyces cerevisiae, a simple eukaryote with about 17 small chromosomes. It involved essentially transferring log-phase cells uniformly labelled by growth in the presence of a radioactive DNA precursor into medium lacking the label. Cell autoradiographs were prepared of samples taken at the time of the transfer and at intervals up to three generations later. So far, less than a dozen strains have been examined, and all but one of these show little evidence for anything other than random distribution of labelled DNA molecules at each mitosis. However, in the single exceptional case of a " rho-zero" cytoplasmic petite mutant, a bi-modal frequency distribution of grain counts emerged at 3 generations, about half the cells in the population at this time being almost free of label. The data are consistent with the model first proposed for bacteria by Lark (Bacterial. Rev., 30, 3, 1966) in which DNA single strands, when first used as templates, become permanently attached to the segregation apparatus. It is implicit that in this strain at least, exchanges between sister chromatids are too few to obscure detection of the phenomenon. It is of interest that the respiratory competent grande parent of this strain showed only a random segregation pattern. Further studies are in progress.

\section{UNCOUPLING OF NUCLEAR AND MITOCHONDRIAL DNA SYNTHESIS IN A TEMPERATURE SENSITIVE MUTANT OF SACCHAROMYCES CEREVISIAE}

\section{K. M. V. RICHMOND}

National Institute for Medical Research, Mill Hill, London

A temperature sensitive mutant $(t s 47)$ has been isolated, in which mitochondrial DNA (mtDNA) can accumulate to high levels at the restrictive temperature $\left(37^{\circ} \mathrm{C}\right)$. When an 
asynchronous culture is transferred $t 037^{\circ} \mathrm{C}$, cell division continues for about one generation then ceases abruptly and cells accumulate at a uniform morphology. This behaviour is typical of cell cycle mutants as described by Hartwell (Bact. Rev., 38, 164-198, 1974). In this mutant the "terminal phenotype" at $37^{\circ} \mathrm{C}$ is a large cell with an equal sized bud, and one nucleus, which remains in the mother cell. Nuclear DNA synthesis ceases about the same time as cell division and shows no further increase thereafter. The block therefore appears to be in an early stage of nuclear division.

In contrast to nuclear DNA, mtDNA continues to be synthesised for over six hours at $37^{\circ} \mathrm{C}$ and accumulates to over 50 per cent of total cellular DNA. Uncoupling of mtDNA synthesis has been reported in certain other cell cycle mutants (Newlon and Fangman, Cell, 5, 423-428, 1975), but low viability is a problem in these mutants. Preliminary results suggest that a high rate of recovery from the blocked state may be achieved in $t s 47$, in which case it should be of considerable use for differential labelling of mtDNA, and for investigation of the regulation of $\mathrm{mtDNA}$ synthesis.

The mutant phenotype has been shown to be due to two recessive nuclear mutations. Both are necessary for temperature sensitivity, and no phenotype has yet been found for either mutation alone. 